Tomasz Zdrojewski1, 2, Agata Ignaszewska-Wyrzykowska1 , Elżbieta Czerniawska-Badtke ${ }^{3}$, Małgorzata Myśliwiec ${ }^{4}$, Ewa Semetkowska-Jurkiewicz ${ }^{5}$, Anna Korzon-Burakowska1, Leszek Czupryniak ${ }^{6,7}$

'Zakład Prewencji i Dydaktyki, Katedra Nadciśnienia Tętniczego i Diabetologii, Gdański Uniwersytet Medyczny

${ }^{2}$ Narodowy Instytut Zdrowia Publicznego - Państwowy Zakład Higieny w Warszawie

${ }^{3}$ Departament Zdrowia, Urząd Marszałkowski Województwa Pomorskiego

${ }^{4}$ Katedra i Klinika Pediatrii, Diabetologii i Endokrynologii, Gdański Uniwersytet Medyczny

${ }^{5}$ Katedra Nadciśnienia Tętniczego i Diabetologii, Gdański Uniwersytet Medyczny

${ }^{6}$ Klinika Chorób Wewnętrznych i Diabetologii, Uniwersytet Medyczny w Łodzi

${ }^{7}$ Klinika Diabetologii i Chorób Wewnętrznych, Warszawski Uniwersytet Medyczny

\title{
Projekt utworzenia sieci ośrodków diabetologicznych w województwie pomorskim
}

\author{
Project of diabetes centers network in Pomorskie
}

\section{STRESZCZENIE}

Wstęp. Cukrzyca stanowi ważny problem zdrowotny i ekonomiczny w Polsce. W województwie pomorskim choruje na nią około 110 tysięcy osób powyżej 18. roku życia. Co czwarty pacjent spośród nich jest nieświadomy posiadania choroby. Szacuje się, że liczba osób chorych na cukrzycę w Polsce i na Pomorzu będzie szybko wzrastać ze względu na coraz większą zapadalność oraz starzenie się społeczeństwa.

Głównym celem niniejszego artykułu jest przedstawienie optymalnego dla województwa pomorskiego modelu sieci ośrodków diabetologicznych. Jego głównym założeniem ma być redukcja liczby hospitalizacji chorych z cukrzycą oraz zdecydowana poprawa opieki ambulatoryjnej.

Materiał i metody. Oceniono dane dotyczące hospitalizacji osób z rozpoznaną cukrzycą w całym województwie pomorskim, uzyskane z bazy Pomorskiego Oddziału NFZ oraz dane osób hospitalizowanych z powodu cukrzycy w Uniwersyteckim Centrum Klinicznym w Gdańsku (szpitalu dysponującym jedynym oddzia-

Adres do korespondencji:

dr hab. med. Tomasz Zdrojewski, prof. nadzw.

Zakład Prewencji i Dydaktyki,

Katedra Nadciśnienia Tętniczego i Diabetologii

Gdański Uniwersytet Medyczny

ul. Dębinki 7, 80-211 Gdańsk

Tel./faks: (58) 3492538

e-mail: tz@gumed.edu.pl

Diabetologia Kliniczna 2015, tom 4, 5, 210-217

DOI: 10.5603/DK.2015.0025

Nadesłano: 14.07.2015

Przyjęto do druku: 10.11.2015 łem diabetologicznym w województwie). Następnie odniesiono się do aktualnych zaleceń towarzystw naukowych i wskazano wady obecnego systemu leczenia osób chorujących na cukrzycę. Ostatecznie zaproponowano model sieci ośrodków diabetologicznych dla województwa pomorskiego.

Wyniki. Wyniki przedstawiono osobno dla opieki szpitalnej i ambulatoryjnej. Zaproponowano sieć 4 szpitali dla opieki całodobowej, zwracając uwagę na potrzeby finansowe, sprzętowe oraz wymagany personel. W opiece ambulatoryjnej zaproponowano szereg rozwiązań, zwłaszcza dotyczących opieki nad osobami młodymi z cukrzycą typu 1, kobietami ciężarnymi oraz pacjentami z zespołem stopy cukrzycowej. (Diabet. Klin. 2015; 4, 5: 210-217)

Słowa kluczowe cukrzyca, opieka ambulatoryjna, opieka szpitalna

\section{ABSTRACT}

Introduction. Diabetes is an important health and economical problem in Poland. Pomorskie Region has a population of about 110.000 adult diabetics. Every fourth of them is unaware of having the disease. It is estimated that the number of people with diabetes in Poland will rapidly increase due to population aging. Aim. The aim of this article is to describe the optimal model of diabetes centers network in Pomorskie to reduce the number of hospitalizations of patients with diabetes and to improve outpatient care. 
Material and methods. Data of hospital care of diabetics in Pomorskie from National Health Service and from the University Clinical Centre in Gdansk was evaluated and compared to the current guidelines. Then defects of current healthcare on diabetics was indicated. Finally, the model of diabetes centers network in Pomorskie was proposed.

Results. Results are presented separately for hospital and outpatient care. The network of four hospitals was proposed depending of the financial needs, required equipment and staff. In outpatient care several solutions was suggested, e.g. healthcare for young people with type 1 diabetes, pregnant women and patients with diabetic foot syndrome. (Diabet. Klin. 2015; 4, 5: 210-217)

Key words: diabetes, outpatient care, hospital care

\section{Wstęp}

Cukrzyca stanowi ważny problem zdrowotny i ekonomiczny w Polsce. Z danych z ogólnopolskich programów badawczych wynika, że na cukrzycę choruje około 2,5 mln dorosłych Polaków [badania NATPOL, PolSenior, 2011, spis Głównego Urzędu Statystycznego (GUS)]; spośród nich prawie co trzeci jest leczony insuliną [1-3]. W województwie pomorskim daje to liczbę 110 tysięcy osób powyżej 18. roku życia chorych na cukrzycę. Alarmujący jest fakt, że co czwarty pacjent spośród nich jest nieświadomy posiadania choroby. Około 26 tysięcy osób nie wie o chorobie, dlatego niefarmakologiczna i farmakologiczna terapia będzie u nich wdrażana z dużym opóźnieniem, powodując wczesne wystąpienie poważnych powikłań.

Najbardziej aktualne badania epidemiologiczne wskazują, że kolejne 95,5 tysiąca dorosłych Pomorzan (niewiele mniej niż chorych na cukrzycę) ma stan przedcukrzycowy.

Na podstawie nowoczesnych metod modelowania statystycznego szacuje się, że liczba osób chorych na cukrzycę w Polsce i na Pomorzu będzie szybko wzrastać ze względu na coraz większą zapadalność związaną m.in. ze starzeniem się społeczeństwa, a także z poprawą skuteczności leczenia chorób układu krążenia przejawiającego się np. zmniejszeniem śmiertelności osób z zawałem serca (ryc. 1). Prognozowana liczba chorych w województwie pomorskim w latach 2011-2030 zmieni się z 110 tysięcy do 180-200 tysięcy.

Epidemia cukrzycy staje się zatem jednym z najważniejszych problemów zdrowotnych, wymagających znacznego zwiększenia nakładów finansowych na opiekę ambulatoryjną i szpitalną. Już teraz niezbędne jest $z$ jednej strony opracowanie działań prewencyj-

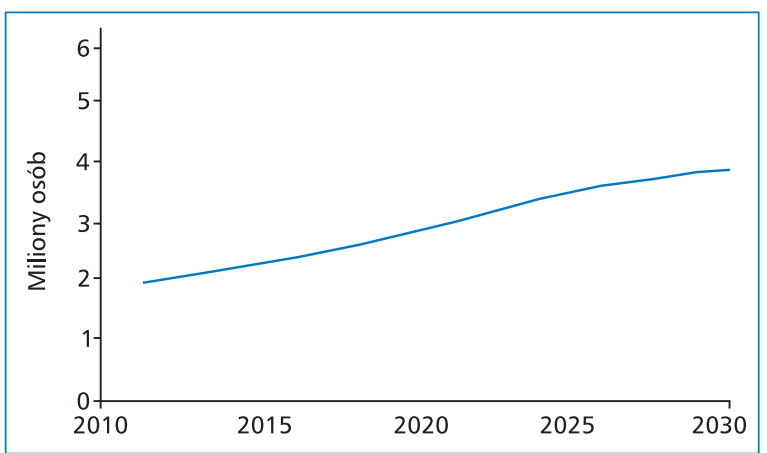

Rycina 1. Prognozowana zmiana liczby osób chorujących na cukrzycę w Polsce w latach 2011-2030

nych, z drugiej zaś zdecydowana poprawa organizacji opieki szpitalnej, redukcja kosztów oraz zwiększenie kadr, szczególnie lekarzy diabetologów.

Głównym celem niniejszego artykułu jest przedstawienie modelu sieci ośrodków diabetologicznych w województwie pomorskim. Założeniem modelu ma być:

1. Redukcja liczby hospitalizacji chorych z cukrzycą o 15-20\%;

2. Skrócenie średniego czasu hospitalizacji o 10-15\% w wyniku bardziej skutecznej terapii chorych z cukrzycą;

3. Umożliwienie odbywania specjalizacji z diabetologii odpowiedniej liczbie lekarzy;

4. Zdecydowana poprawa opieki ambulatoryjnej m.in. poprzez wyodrębnienie oraz merytoryczne, organizacyjne i finansowe zróżnicowanie porad ambulatoryjnych $\mathrm{u}$ :

- kobiet ciężarnych,

- osób z cukrzycą typu 1, w tym leczonych za pomocą osobistych pomp insulinowych,

— osób z zespołem stopy cukrzycowej;

5. Poprawa dostępu do specjalistycznego leczenia szpitalnego dla chorych na cukrzycę poprzez zwiększenie liczby oddziałów szpitalnych z kontraktem z Narodowym Funduszem Zdrowia (NFZ) na świadczenia diabetologiczne.

\section{Materiał i metody}

Aby przygotować optymalny dla potrzeb województwa model opieki diabetologicznej, postanowiono rozpocząć od poddania analizie sytuacji osób chorujących na cukrzycę dzięki informacjom zgromadzonym w latach 2009-2012.

Pierwszym etapem pracy było przeprowadzenie oceny:

- danych dotyczących hospitalizacji osób z rozpoznaną cukrzycą w całym województwie pomorskim, uzyskanych z bazy Pomorskiego Oddziału NFZ; 
- danych dotyczących osób hospitalizowanych z powodu cukrzycy w Uniwersyteckim Centrum Klinicznym w Gdańsku (UCK - szpitalu dysponującym jedynym oddziałem diabetologicznym w województwie).

Odniesiono się do aktualnych zaleceń towarzystw naukowych i wskazano wady obecnego systemu leczenia osób chorujących na cukrzycę. Ostatecznie zaproponowano optymalny pod względem merytorycznym, organizacyjnym i finansowym model sieci ośrodków diabetologicznych dla województwa pomorskiego. Wyniki przedstawiono osobno dla opieki szpitalnej i ambulatoryjnej, niemniej proponowany model stanowi integralną całość.

\section{Wyniki}

\section{Opieka szpitalna w cukrzycy - ocena sytuacji} bieżącej

W opiece szpitalnej, według aktualnych zaleceń, liczba hospitalizacji będzie zależeć od liczby osób z:

- nowo wykrytą cukrzycą typu 1 oraz cukrzycą typu 2 z klinicznymi objawami hiperglikemii;

- ostrymi powikłaniami cukrzycy (zarówno hiper-, jak i hipoglikemii) lub z zaostrzeniem przewlekłych powikłań;

- brakiem efektów terapii w warunkach ambulatoryjnych lub wymagających wykonania drobnych zabiegów;

- koniecznością wdrożenia intensywnej terapii z użyciem pompy insulinowej;

- cukrzycą ciążową lub przedciążową, wymagających insulinoterapii $[4,5]$.

Niemożliwe jest w chwili obecnej, bez szczegółowych rejestrów, oszacowanie liczby chorych wymagających hospitalizacji z wyżej wymienionych powodów. Nierzadko zdarza się, że chorzy ze świeżo wykrytą cukrzycą bądź rozpoczynający leczenie za pomocą pompy insulinowej w ogóle nie trafiają do szpitala. W dalszej perspektywie może to powodować zwiększone ryzyko wystąpienia powikłań.

Jednocześnie nie sposób określić, czy wszystkie osoby z cukrzycą kierowane do szpitali rzeczywiście wymagają takiej opieki zamiast skutecznego leczenia ambulatoryjnego. W niektórych europejskich analizach podkreśla się zbyt dużą liczbę hospitalizacji chorych z cukrzycą w Polsce, co wynika z niedoskonałości opieki ambulatoryjnej [6]. W krajach o dobrze rozwiniętej opiece diabetologicznej, jak np. w Holandii, Wielkiej Brytanii, krajach skandynawskich, inicjowanie leczenia insuliną u osób z cukrzycą typu 2 odbywa się całkowicie w warunkach ambulatoryjnych i do tego modelu należy dążyć także w Polsce. W niektórych krajach nie hospitalizuje się automatycznie wszystkich chorych z nowo rozpoznaną cukrzycą typu 1, jeżeli ich stan kliniczny tego nie wymaga, czyli nie znajdują się w stanie zaawansowanej kwasicy ketonowej. Leczenie insuliną inicjuje się w warunkach ambulatoryjnych, gdzie jest także prowadzona kompleksowa edukacja.

W województwie pomorskim dzięki danym z NFZ oszacowano liczbę hospitalizacji w latach 2009-2011. Liczba osób przyjmowanych z powodu cukrzycy na oddziały internistyczne wyniosła średnio 2524/rok (4,9\% wszystkich hospitalizowanych). Dodatkowo chorzy na cukrzycę stanowili istotny odsetek osób hospitalizowanych z powodu innych przyczyn (ponad 11\%), a także ze względu na częste powikłania cukrzycy byli pacjentami oddziałów kardiologicznych, nefrologicznych, neurologicznych, chirurgicznych i dermatologicznych, stanowiąc odsetek co najmniej 3-12\% wszystkich chorych. Warto wspomnieć o niedostatecznej wiarygodności danych raportowanych do NFZ o chorobach towarzyszących. Często dane te są mocno niekompletne, o ile nie mają znaczenia dla rozliczenia pobytu w szpitalu. W związku z tym odsetek osób z cukrzycą hospitalizowanych z innych przyczyn może być znacząco większy niż wskazują powyższe dane.

Zgodnie z zarządzeniem Prezesa NFZ możliwe jest leczenie cukrzycy i większości jej powikłań zarówno na oddziałach diabetologicznych, jak i internistycznych [7]. Dodatkowo powikłania cukrzycy mogą być leczone na oddziałach neurologicznych, kardiologicznych, okulistycznych, nefrologicznych, endokrynologicznych i chirurgicznych, jak i oczywiście pediatrycznych w przypadku chorych dzieci i młodzieży.

W województwie pomorskim obecnie funkcjonuje jeden oddział internistyczny z pododdziałem diabetologicznym (Klinika Nadciśnienia Tętniczego i Diabetologii UCK w Gdańsku), w którym kontrakt na diabetologię w 2012 roku pozwolił na leczenie jedynie 110 pacjentów i zakończył się w na przełomie maja i czerwca 2012 roku. Dla porównania w latach wcześniejszych (2010-2011) leczono w Klinice 185 osób rocznie z powodu cukrzycy. Oznacza to, że jedynie 7,5\% spośród wszystkich pacjentów z cukrzycą wymagających hospitalizacji trafiło do wyspecjalizowanego ośrodka, a wobec znacznego zmniejszenia wydatków na diabetologię w ubiegłym roku liczba ta spadła nawet do $4 \%$.

Pozostali pacjenci trafiają na oddziały internistyczne, gdzie często nie ma możliwości przeprowadzenia specjalistycznych konsultacji, leczenia i edukacji przez zespół posiadający doświadczenie w zakresie diabetologii. Jednocześnie pacjenci są kierowani do szpitali bez wcześniejszej weryfikacji przez specjalistę diabetologa, dotyczącej konieczności leczenia w warunkach szpitalnych, gdy wystarczająco skutecznie mogliby być leczeni w poradniach specjalistycznych. 
Warto również podkreślić, jak duży odsetek chorych na cukrzycę trafia na inne oddziały specjalistyczne z powodu powikłań cukrzycy. W województwie pomorskim liczba hospitalizacji na oddziałach neurologicznych, kardiologicznych, nefrologicznych, chirurgicznych osób ze współistniejącym rozpoznaniem cukrzycy wynosi rocznie ponad 5000. Z pewnością liczbę tę można byłoby istotnie zmniejszyć dzięki skuteczniejszemu leczeniu cukrzycy w warunkach ambulatoryjnych oraz w sieci oddziałów diabetologicznych.

\section{Model sieci szpitalnych oddziałów \\ diabetologicznych w województwie pomorskim \\ Lokalizacja}

Poprawę jakości leczenia cukrzycy i jej powikłań umożliwiłoby utworzenie sieci oddziałów diabetologicznych (lub pododdziałów w ramach istniejących oddziałów internistycznych). Sieć taka miałaby obejmować kilka szpitali rozproszonych na terenie województwa, tak by umożliwić szybkie dotarcie do ośrodka z każdego miejsca. Proponuje się utworzenie oddziałów diabetologicznych w 4 miastach: Gdańsku, Chojnicach, Malborku i Słupsku.

Sugerując się średnią liczbą osób hospitalizowanych z powodu cukrzycy na oddziałach internistycznych, oszacowano minimalną liczbę hospitalizacji z powodu cukrzycy na 2500. Zakłada się, że nieduża część pacjentów z cukrzycą nadal będzie trafiać na najbliższe oddziały ratunkowe, a potem oddziały chorób wewnętrznych. Pozostała grupa pacjentów wstępnie kierowana do szpitala zostanie poddana weryfikacji zgłoszenia przez diabetologa i na tej podstawie kwalifikowana do opieki szpitalnej bądź ambulatoryjnej. Z czasem, dzięki poprawie skuteczności leczenia, zakłada się zmniejszenie liczby hospitalizacji osób z cukrzycą na innych oddziałach specjalistycznych. W związku z tym globalna liczba hospitalizacji z powodu cukrzycy zmniejszy się, zarazem jednak te hospitalizacje, które się odbędą, będą znacząco bardziej uzasadnione i przez to skuteczniejsze w zakresie osiągnięć celów terapii cukrzycy w dalszej perspektywie. Szacuje się, że minimalna ich liczba na oddziałach diabetologicznych będzie wynosić około 2000 rocznie.

Z obserwacji własnych wynika, że jedno łóżko o profilu diabetologicznym rocznie może służyć 50 chorym. Przy zakładanej minimalnej liczbie 2000 hospitalizacji konieczne będzie stworzenie 40 łóżek w sieci 4 szpitali.

Największą liczbę hospitalizacji przewiduje się w Gdańsku, wobec najliczniejszej populacji Trójmiasta w skali województwa. Określona większa liczba łóżek w Gdańsku ma odgrywać jeszcze jedną istotną rolę dla pomorskiej diabetologii — funkcję szkoleniową. Warto podkreślić, że liczba osób posiadających specjalizację z diabetologii w województwie pomorskim wynosi obecnie około 50. Aby zapewnić optymalną opiekę ambulatoryjną i szpitalną, ich liczba powinna się zwiększyć przynajmniej o połowę. Nierzadko jednak z powodu braku miejsc szkoleniowych lekarze zainteresowani tą specjalizacją migrują do innych województw, zasilając tam kadrę medyczną.

\section{Organizacja oddziałów szpitalnych}

Postuluje się tworzenie oddziałów diabetologicznych zgodnie $z$ aktualnymi zaleceniami polskimi i europejskimi, a także zgodnie z wymogami NFZ. Zgodnie z zaleceniami organizacyjnie oddział powinien zapewnić:

- opiekę personelu lekarskiego, w tym dwóch diabetologów;

- opiekę personelu pielęgniarskiego, w tym dwie pielęgniarki na stanowisku edukatora, których zakres obowiązków jest ograniczony do edukacji i opieki nad chorymi na cukrzycę;

- dietetyka i psychologa posiadających zakres obowiązków ograniczony tylko do opieki diabetologicznej;

- dostęp do konsultacji specjalistycznych i badań diagnostycznych [4].

Na każde 16-20 łóżek diabetologicznych zaleca się następujący skład zespołu: 2-3 lekarzy, 2 pielęgniarki na stanowisku edukatora, dietetyk oraz psycholog i pracownik socjalny.

Istotnym wyposażeniem oddziału diabetologicznego powinno być co najmniej 1 stanowisko intensywnego nadzoru metabolicznego na każde 8-10 łóżek oraz sala edukacyjna.

\section{Potrzeby finansowe}

Zgodnie z obecnymi zarządzeniami Prezesa NFZ na oddziale diabetologicznym dla osób dorosłych zakontraktowanych jest obecnie 9 jednorodnych grup pacjentów (JGP) o różnej wartości punktowej hospitalizacji w zależności od przyczyny i trybu przyjęcia (tab. 1).

Zakładając równy rozkład częstości poszczególnych grup JGP, średnia arytmetyczna jednej hospitalizacji wynosi 52 punkty. Jednak z obserwacji prowadzonych w UCK wynika, że częstość kwalifikowania do poszczególnych grup JGP waha się od $0 \%$ do $52 \%$, wobec czego realna średnia wartość zwrotu NFZ za hospitalizację w 2012 roku wyniosła 53,5 punktu.

Odrębnym bardzo istotnym zagadnieniem jest istotnie niedoszacowana wartość punktu w przypadku hospitalizacji diabetologicznych, zwłaszcza w zespole stopy cukrzycowej. Przykładem mogą być pobyty w Klinice Nadciśnienia Tętniczego i Diabetologii w Gdańsku pacjentów, u których na leki, badania i procedury me- 
Tabela 1. Jednorodne grupy pacjentów (JPG) związane bezpośrednio z hospitalizacją dorosłych osób chorych na cukrzycę

\begin{tabular}{llcc}
\hline Kod JGP & Nazwa grupy & $\begin{array}{c}\text { Wartość punktowa } \\
\text { - hospitalizacja pilna }\end{array}$ & $\begin{array}{c}\text { Wartość punktowa } \\
\text { - hospitalizacja planowa }\end{array}$ \\
\hline A31 & Choroby nerwów obwodowych & 30 & 29 \\
K26 & Zaburzenia wodno-elektrolitowe & 28 & 27 \\
K27A & Zaburzenia odżywienia & 50 & 48 \\
K28 & Wrodzone wady metaboliczne & 86 & 82 \\
K35 & Cukrzyca z powikłaniami i inne stany hipoglikemiczne & 44 & 42 \\
K37 & Cukrzyca ze stanami hiperglikemicznymi & 48 & 46 \\
K38 & Cukrzyca i stany hiperglikemiczne innego pochodzenia & 44 & 42 \\
K39 & Stopa cukrzycowa & 83 & 83 \\
L84 & Inne choroby nerek & 61 & 61 \\
\hline
\end{tabular}

dyczne (nie wliczając kosztów osobowych, wyżywienia itp.) wydawano kilkukrotnie więcej niż według zasad rozliczania NFZ.

Niemniej przy planowanych minimum 2000 hospitalizacji na rok dla całego województwa konieczne byłoby przeznaczenie przynajmniej 5,6 mln złotych rocznie na potrzeby 4 oddziałów/pododdziałów diabetologicznych.

Docelowo kierunkiem działań w opiece diabetologicznej powinna być zmiana proporcji między skuteczną opieką ambulatoryjną i konieczną tylko w określonych sytuacjach opieką szpitalną, tak aby zmienić niekorzystne wskaźniki w porównaniu z innymi państwami OECD. Zmiana ta przyniesie także ogromne oszczędności w finansowaniu leczenia cukrzycy, gdyż opieka ambulatoryjna kosztuje wielokrotnie mniej niż szpitalna, wiąże się także z dużo mniejszym ryzykiem powikłań terapii (zakażenia wewnątrzszpitalne itp.).

\section{Opieka ambulatoryjna w cukrzycy}

W 2010 roku w województwie pomorskim odnotowano około 120000 porad cukrzycowych. Zgodnie z zaleceniami Polskiego Towarzystwa Diabetologicznego (PTD) do opieki specjalistycznej powinni być kierowani: - wszyscy chorzy leczeni insuliną oraz z powikłaniami -2-3 razy w roku, w tym chorzy z cukrzycą typu 1, u których wskazana jest regularna kontrola co 2 miesiące. Szacuje się, że chorych z cukrzycą typu 1 w województwie pomorskim jest około 7000, zaś leczonych insuliną 30 000;

- każdy chory z rozpoznaną cukrzycą - 1 raz w roku. Kompleksowa opieka ambulatoryjna, zakładająca finansowanie leczenia specjalistycznego na drodze stawki kapitacyjnej (podobnie jak w warunkach podstawowej opieki zdrowotnej), powinna być szeroko realizowana w ramach świadczeń Kompleksowej Ambulatoryjnej Opieki Specjalistycznej (KAOS), jednak przy obecnych warunkach finansowych taki sposób leczenia nie jest opłacalny dla zakładów opieki medycznej i coraz mniej jednostek podpisuje ten rodzaj kontraktu z NFZ.

Inną metodą zwiększenia skuteczności opieki nad chorym z cukrzycą byłoby rozszerzenie zakresu katalogu usług poprzez oddzielne kontraktowanie w strukturach poradni diabetologicznej:

- poradni leczenia osobistymi pompami insulinowymi;

- poradni dla kobiet ciężarnych;

- poradni stopy cukrzycowej.

Poradnia cukrzycy typu 1 (opieka pediatryczna i dla młodych dorosłych)

Szacuje się, że na świecie na cukrzycę typu 1 choruje ponad 215000 dzieci. Ich liczba w ciągu ostatnich 25 lat podwoiła się i prognozuje się, że w ciągu następnych 20 lat ulegnie dalszemu podwojeniu. W województwie pomorskim już teraz jest ponad 1000 dzieci z cukrzycą typu 1. Każdego roku około 100 pacjentów po ukończeniu 18. roku życia jest przekazywana do poradni dla dorosłych. Większość z tej grupy jest leczona za pomocą osobistych pomp insulinowych. Oznacza to, że w ciągu najbliższych 5 lat znacznie wzrośnie liczba dorosłych chorych z cukrzycą typu 1 leczonych przy użyciu osobistej pompy insulinowej.

Przejście z poradni pediatrycznej do poradni dla dorosłych wiąże się z licznymi dodatkowymi problemami związanymi z przejściowym etapem pomiędzy dzieciństwem a dorosłością. W okresie dojrzewania dochodzi do pogorszenia kontroli glikemii z powodu:

- nieregularnego spożywania posiłków i nieregularnej aktywności fizycznej;

- niedostatecznego stosowania się do schematów leczenia;

- ryzykownych zachowań;

- zaburzeń odżywiania (pomijanie dawek insuliny w celu zmniejszenia masy ciała, bulimia, anoreksja);

- zmian hormonalnych związanych z dojrzewaniem płciowym. 
Obecnie obserwuje się pogorszenie wyników leczenia pacjentów z cukrzycą typu 1 wraz z przejściem z poradni diabetologicznych pediatrycznych do nieprzygotowanych poradni dla dorosłych. W czasie „przejścia” część pacjentów „wypada” ze specjalistycznej opieki, pozostając tylko pod opieką lekarza rodzinnego, bądź zmniejsza się częstość wizyt w poradniach diabetologicznych. Często następuje zmiana metody insulinoterapii, np. z terapii „pompowej" na penową. Chorzy też nie są przygotowani na zupełnie inny charakter wizyt w poradni dla osób dorosłych (krótszy czas wizyty, pełna odpowiedzialność za stan zdrowia spoczywa na pacjencie itp.).

Skutkiem pogorszenia wyników leczenia pacjentów z cukrzycą typu 1 jest zwiększenie częstości ostrych powikłań i związana z tym konieczność hospitalizacji, a więc wzrostu kosztów leczenia. Dodatkowo zwiększa się częstość rozwoju późnych powikłań choroby, przede wszystkim w postaci nefropatii i retinopatii cukrzycowej.

Przede wszystkim przejście do systemu ochrony zdrowia dla osób dorosłych nie powinno nieść za sobą nagłej nieoczekiwanej zmiany, lecz powinien to być zorganizowany proces adaptacji. W 2013 roku PTD opracowało metodologię przekazywania chorych spod opieki pediatrycznej do internistycznej [4].

Należy z całą mocą podkreślić szczególny charakter wizyt pacjenta leczonego przy użyciu osobistej pompy w poradni diabetologicznej, mający związek z kosztami leczenia takiego pacjenta. Wizyta ta trwa znacząco dłużej od przeciętnej, nawet pacjenta z cukrzycą typu 1 leczonego tradycyjnie, bez użycia pompy — od 30 do 45 minut. W jej trakcie wykonuje się bowiem komputerowy odczyt danych z pompy i glukometru, a następnie analizuje się ten zapis wraz z chorym. Każda inna metoda realizacji wizyty pacjenta z pompą insulinową jest niewłaściwa i stanowi w istocie stratę czasu. Wizyty te powinny być zatem finansowane inaczej niż zwykła porada diabetologiczna (patrz niżej).

\section{Rozwiązania dotyczące przeniesienia pacjenta z systemu opieki pediatryczno-diabetologicznej do systemu opieki dla dorosłych}

\section{Lokalizacja}

Konieczne jest wytypowanie poradni diabetologicznych zdolnych do zapewnienia profesjonalnej opieki młodym dorosłym chorym na cukrzycę typu 1, szczególnie stworzenie poradni zajmującej się wyłącznie leczeniem za pomocą osobistych pomp insulinowych (min. $1 \mathrm{w}$ województwie)

2. Kwalifikacje zespołu terapeutycznego:

- diabetolog doświadczony w zakresie leczenia metodą intensywnej insulinoterapii, szczególnie za pomocą osobistych pomp insulinowych;

— pielęgniarka edukacyjna (trener pompowy);
- dietetyk posiadający odpowiednie kwalifikacje w zakresie żywienia chorych na cukrzycę;

- psycholog mający doświadczenie w pracy z chorobą przewlekłą.

3. Wyposażenie poradni w specjalistyczny sprzęt zgodnie z zaleceniami klinicznymi PTD, m.in.:

- system ciągłego monitoringu glikemii (CGMS, continuous glucose monitoring system);

- sprzęt komputerowy posiadający oprogramowanie do odczytywania danych z glukometrów, pomp insulinowych oraz CGMS.

4. Proponowane zmiany w kontraktowaniu:

- oddzielne kontraktowanie poradni pompowej;

- zmiana zasad finansowania porad „pompowych” ze względu na dłuższy czas trwania wizyty (do 45 minut) oraz konieczność jej realizacji wyłącznie przez wysoko wykwalifikowany zespół;

- zapewnienie częstszych wizyt kontrolnych w celu uzyskania jak najlepszych wyników leczenia;

- zapewnienie możliwości konsultacji zarówno w poradni, jak i telefonicznych w ciągu całej doby.

\section{Poradnia dla ciężarnych}

Aktualnie katalog NFZ nie przewiduje odrębnego finansowania poradni dla ciężarnych z cukrzycą. Pozostają one pod opieką poradni diabetologicznej (w przypadku cukrzycy rozpoznanej przed ciążą) lub poradni położniczej (w przypadku cukrzycy ciążowej).

Szczególnym problemem jest realizacja porad dla ciężarnych z cukrzycą ciążową, która odbywa się w ramach Poradni Patologii Ciąży. Pacjentki przybywające na wizytę mają możliwość kontaktu z lekarzem położnikiem, ale nie z diabetologiem. Obecny system, po pierwsze, nie przewiduje wyodrębnienia osobnych środków finansowych niezbędnych do opieki nad ciężarną z cukrzycą (w tym pokrycie szeregu koniecznych badań dodatkowych, nieobjętych refundacją). Po drugie — nie ułatwia pacjentowi przybywającemu często z daleka kontaktu z dwoma specjalistami jednocześnie, co jest wysoce niekorzystne dla bezpieczeństwa ciąży i kobiety.

Proponuje się wyodrębnienie w ramach struktur Poradni Położniczej poradni tylko dla kobiet z cukrzycą ciążową, prowadzonej przez lekarza położnika. Jednocześnie priorytetem jest koordynacja wizyt w poradni kobiet z cukrzycą ciążową z wizytami diabetologicznymi, tak aby pacjentka przybywająca do Gdańska mogła uzyskać dwie porady w jednym dniu. Ośrodkiem, którego zadaniem byłaby koordynacja wizyt, powinno być Regionalne Centrum Diabetologii UCK jako ośrodek nadrzędny.

\section{Plan zmian dla ciężarnych z cukrzycą ciążową}

Proponuje się następujący plan zmian dla ciężarnych z cukrzycą ciążową: 
- utworzenie konsultacyjnej placówki położniczej ze względu na możliwość uzyskania natychmiastowej pomocy położniczej w sytuacji zagrożenia dla płodu. W stanach znacznie niewyrównanej glikemii lub wprowadzania intensywnej insulinoterapii - możliwość diagnostyki i leczenia w ramach hospitalizacji na oddziale patologii ciąży;

- zabezpieczenie stałej i codziennej opieki doświadczonego diabetologa i dietetyka w czasie hospitalizacji na oddziale patologii ciąży;

- stworzenie ambulatoryjnego programu diagnostyki prenatalnej I i II trymetru ciąży dla ciężarnych z cukrzycą przedciążową (typ 1, 2):

- w I trymestrze refundacja badań diagnostyki prenatalnej: test „podwójny” (PAPP-A), ultrasonografia „genetyczna", ocena kariotypu płodu w wybranych przypadkach;

- w II trymestrze refundacja badania ultrasonograficznego z oceną serca płodu (ECHO serca płodu) z oceną kariotypu płodu w wybranych przypadkach;

- na wszystkich etapach ciąży refundacja oceny ponadstandardowych w opiece nad ciężarną parametrów laboratoryjnych (OGTT — test 75 g glukozy, $\mathrm{HbA}_{1 c^{\prime}}, \mathrm{GAD}, \mathrm{C}$-peptyd, badanie ogólne moczu);

- możliwość współpracy z położną - edukatorem w cukrzycy;

- nieograniczony limit porad udzielanych ciężarnej z cukrzycą.

\section{Poradnia stopy cukrzycowej}

Pomimo braku dokładnych danych epidemiologicznych szacuje się, że zespół stopy cukrzycowej w województwie pomorskim może dotyczyć 10-15 tysięcy pacjentów - taka liczba chorych wymaga specjalistycznej opieki. Obecnie na terenie województwa pomorskiego funkcjonuje tylko jeden gabinet stopy cukrzycowej, co oznacza, że chorzy są zmuszeni dojeżdżać na wizytę nawet ponad 100 kilometrów. Powoduje to, że wielu pacjentów nie jest w stanie stawiać się na wizyty kontrolne z odpowiednią częstością zarówno ze względów organizacyjnych, jak i finansowych. Oznacza to również, że nie mogą oni być właściwie leczeni. Podstawę terapii stanowi bowiem regularny nadzór nad raną i bezwzględne odciążenie chorej kończyny — długie podróże stanowią zaprzeczenie podstawowych zasad terapii.

Personel jednej poradni w województwie nie jest w stanie zapewnić właściwej opieki wszystkim chorym z zespołem stopy cukrzycowej. Konieczne jest zatem utworzenie nowych ośrodków. Najlepiej, aby były one zlokalizowane przy szpitalach proponowanej sieci, mających zaplecze diagnostyczne (radiologia, laboratorium, pracownia mikrobiologiczna) i mogących $w$ razie potrzeby hospitalizować pacjentów na oddziałach chorób wewnętrznych lub chirurgicznych. Należy jednak podkreślić, że właściwie sprawowana opieka ambulatoryjna pozwala uniknąć kosztownych hospitalizacji, zmniejsza ogromnie ryzyko amputacji i prowadzi do długofalowego zmniejszenia kosztów leczenia tego powikłania cukrzycy.

\section{Projekt zmian dotyczący gabinetów stopy cukrzycowej}

1. Utworzenie nowych gabinetów stopy cukrzycowej w całym województwie. Optymalnie powinny być one zlokalizowane przy szpitalach lub przy poradniach diabetologicznych mających dostęp do ww. zaplecza.

Proponowane lokalizacje to:

- Gdańsk - jako ośrodek referencyjny;

- Słupsk, Chojnice, Malbork.

2. Wyposażenie:

- sprzęt do badania neuropatii;

- podstawowe narzędzia chirurgiczne do opracowywania ran;

- aparat fotograficzny do prowadzenia dokumentacji procesu gojenia rany oraz $\mathrm{w}$ celu ewentualnej konsultacji z ośrodkiem referencyjnym;

- bezpośredni dostęp do badania USG doplerowskiego tętnic kończyn dolnych.

3. Personel:

- 1-2 specjalistów z dziedziny chirurgii - jako konsultanci;

- diabetolog - osoba sprawująca nadzór nad chorymi leczonymi w gabinecie (obecny zawsze w godzinach funkcjonowania gabinetu);

- 2 pielęgniarki mające przeszkolenie w dziedzinie cukrzycy i leczenia ran;

- dostęp do specjalisty protetyka - możliwość opracowania dla chorych wkładek do butów, protez itp. Niezwykle istotne jest wdrożenie do systemu opieki nad pacjentami z zespołem stopy cukrzycowej pielęgniarek środowiskowych, mogących odwiedzać chorych w domu, zmieniać opatrunki i oceniać postęp gojenia. Za tę działalność pielęgniarki powinny otrzymywać dodatkowe wynagrodzenie związane z większą częstością takich wizyt.

4. Zmiany finansowania gabinetów stopy cukrzycowej powinny obejmować:

- oddzielne kontraktowanie świadczeń dla gabinetów stopy cukrzycowej lub preferencyjne kontraktowanie poradni posiadających takie gabinety;

- zwiększenie wyceny za założenie opatrunku na stopę cukrzycową;

— możliwość zwiększenia wyceny porady związanej z zaopatrzeniem kilku ran na dwóch kończynach; 
- poszerzenie katalogu świadczeń o edukację i profilaktykę stopy cukrzycowej;

- poszerzenie katalogu zabiegów możliwych do wykonywania w poradni stopy cukrzycowej;

- zakontraktowanie chirurga do gabinetu (np. w systemie konsultacyjnym).

\section{Dyskusja/Podsumowanie}

Proponowany model leczenia diabetologicznego w województwie pomorskim ma stanowić kompleksowy system opieki oparty na sieci ośrodków szpitalnych oraz ambulatoryjnych dla chorych na cukrzycę. Warto podkreślić możliwość uzyskania długofalowych oszczędności dzięki rozbudowie opieki ambulatoryjnej, głównie dzięki uniknięciu ostrych i przewlekłych powikłań cukrzycy wymagających często drogich hospitalizacji.

\section{Wnioski}

1. Przygotowanie optymalnego pod względem merytorycznym, organizacyjnym i finansowym modelu sieci ośrodków diabetologicznych szpitalnych i ambulatoryjnych wydaje się konieczne przy narastającym problemie epidemii cukrzycy.

2. Do wprowadzenia przedstawionych wyżej zmian niezbędna będzie współpraca lokalnego środowiska diabetologicznego skupionego w regionalnych oddziałach PTD, samorządu oraz wojewódzkiego oddziału Narodowego Funduszu Zdrowia.

3. W ciągu najbliższych kilku lat należy doprowadzić do zmiany systemu funkcjonowania opieki diabetologicznej, kładąc większy nacisk na skuteczne leczenie ambulatoryjne. Nie uda się to bez ciągłego kształcenia i informowania lekarzy mających pierwszy kontakt z chorymi na cukrzycę (głównie lekarzy rodzinnych i internistów).

\section{Oświadczenie o konflikcie interesów \\ Autorzy nie zgłaszają konfliktu interesów.}

\section{Podziękowania}

Źródłowy dokument był efektem spotkań Grupy Roboczej i ekspertów w ramach programu Zdrowie dla Pomorzan 2005$-2013$.

Lista ekspertów, którzy wzięli udział w pracach nad opracowaniem dokumentu (w kolejności alfabetycznej): Piotr Bandosz, Andrzej Basiński, Elżbieta Czerniawska-Badtke, Maria Czubek, Marzena Głowacz, Agata Ignaszewska-Wyrzykowska, Hanna Jasiel-Wojculewicz, Tadeusz Jędrzejczyk, Jerzy Karpiński, Barbara Kawińska, Katarzyna Kopacz, Anna Korzon-Burakowska, Beata Królikowska-Kobierska, Ewa Książek-Bator, Tomasz Lemańczyk, Bernadetta Lewicka, Elżbieta Mówińska, Małgorzata Myśliwiec, Krzysztof Narkiewicz, Elżbieta Orłowska-Kunikowska, Barbara Ostojska, Małgorzata Paszkowicz, Magdalena Poleszuk, Krzysztof Preis, Marcin Rutkowski, Ewa Semetkowska-Jurkiewicz, Zdzisław Sićko, Mirosława Skiba, Ryszard Stus, Agnieszka Szafrańska, Małgorzata Świątkowska-Freund, Jolanta Wierzbicka, Danuta Wiśniewska-Adamczyk, Ewa Wodzikowska, Bogumił Wolnik, Joanna Wójcicka, Krzysztof Wójcikiewicz, Bogdan Wyrzykowski, Tomasz Zdrojewski, Hanna Zych-Cisoń

\section{PIŚMIENNICTWO}

1. Januszkiewicz-Caulier J., Mossakowska M., Zdrojewski T. i wsp. Cukrzyca i jej powikłania w podeszłym wieku. W: Mossakowska M., Więcek A., Błędowski P. (red.). Aspekty medyczne, psychologiczne, socjologiczne i ekonomiczne starzenia się ludzi w Polsce. Wydawnictwo Termedia, Poznań 2012: 169-180.

2. Rutkowski M., Bandosz P., Czupryniak L. i wsp. Prevalence of diabetes and impaired fasting glucose in Poland - the NATPOL 2011 Study. Diabet. Med. 2014; 31: 1568-1571. doi: 10.1111/dme.12542. Epub 2014 Jul 22.

3. Bandosz P. Zmiany rozpowszechnienia klasycznych czynników ryzyka chorób układu krążenia w Polsce w latach 2002-2011: rozprawa na stopień doktora nauk medycznych. Gdański Uniwersytet Medyczny, Gdańsk 2013.

4. Zalecenia kliniczne dotyczące postępowania u chorych na cukrzycę 2013. Diabetologia Kliniczna 2012; 1 (supl. A): A1-A52.

5. ADA Clinical Practice Recommendations 2012. Diabetes Care 2012; 35 (supl. 1): 1-113.

6. Usprawnienie systemu opieki zdrowotnej. W: Przeglądy gospodarcze OECD: Polska 2012: 51-92.

7. Zarządzenie Nr 89/2013/DSOZ Prezesa Narodowego Funduszu Zdrowia z dnia 19 grudnia 2013 r. w sprawie określenia warunków zawierania i realizacji umów w rodzaju: leczenie szpitalne. 